\title{
170 VARIA Nagość jako strategia promocyjna kina polskiego lat 80.
}

\author{
PIOTR ZWIERZCHOWSKI \\ Instytut Filologii Polskiej i Kulturoznawstwa \\ Uniwersytet Kazimierza Wielkiego w Bydgoszczy
}

\begin{abstract}
Zwierzchowski Piotr, Nagość jako strategia promocyjna kina polskiego lat 80. [Nudity as a promotional strategy in the Polish cinema of the 1980s]. „Images” vol. XXIII, no. 32. Poznań 2018. Adam Mickiewicz University Press. Pp. 170-176. ISSN 1731-450X. DOI 10.14746/i.2018.32.13.

The article examines how nudity was used as a promotional strategy in the Polish cinema in the 1980s. In contrast to earlier decades, the Polish movie industry delivered dozens of films that contained female nudity and erotic scenes. Some actresses like Maria Probosz, became automatically associated with such movies. Paradoxically, the Polish cinema of the 1980s was only slightly concerned with the discourse of eroticism. As Maria Kornatowska writes, The shortage of erotic sensibility was compensated by 'bald nakedness." The reasons for the increased presence of nudity on movie screens stemmed from the transformation of social lifestyle and audiences' demand, the search for easy profit and the need to de-politicize society. Of significant importance were the influences of the growing video market and western cinema. Projections of nudity were meant to divert attention from the bleak reality of Poland enmeshed in crisis provide a sense of belonging to the Western world, and give mostly male viewers visual pleasure. It was also a marketing technique luring viewers to cinemas by bombarding them with daring posters and stills reproduced in the press and in front of movie theaters. My article will discuss and explain the ways of presenting female nudity in terms of these economic and political tasks.
\end{abstract}

KeYwORDs: Polish cinema, 80s, nudity, promotional strategy, film advertisement

W latach 8o. w Polsce powstało kilkadziesiąt filmów zawierających mniej lub bardziej uzasadnione sceny kobiecej nagości. Mimo że stała się ona tak istotnym elementem polskiego kina, przynajmniej ilościowo, paradoksalnie, w niewielkim stopniu zajmowało się ono erotyzmem. Maria Kornatowska już w połowie lat 8o. trafnie zauważyła, że „film polski cierpi na niedostatek erotycznej wrażliwości kompensowany «odważną» golizną, najczęściej bez żadnych motywacji, tudzież rozmaitymi

[1] M. Kornatowska, Eros i film, Łódź 1986, s. 22-23. W innym miejscu autorka zwracała uwagę na lęk przed kobiecością, który próbuje się „kamuflować i rozładowywać na różne sposoby: demonizując kobiety lub je idealizując, «kastrując» ich kobiecość lub czyniąc je przedmiotem voyeuryzmu kamery i widza, żywym elementem dekoracji, ozdobną atrapą. Obecnie, jak się zdaje, w ramach polskiej erupcji seksu przyszedł sezon na ozdobne atrapy". Ibidem, s. 55.

[2] Starać się działać mądrze. Rozmowa z Przemysławem Marciszem, dyrektorem Okręgowego «momentami», którymi szafuje się dość hojnie gwoli przyciągnięcia widzów"[1].

Tak silna obecność nagości nie tylko w kinie, ale i w szeroko rozumianej kulturze popularnej miała jednak znacznie głębsze uzasadnienie, oczywiście silnie powiązane z szeroko rozumianą erotyką, ale także dotyczące jej samej. Wynikała między innymi z przemian obyczajowych, zarówno związanych z codziennym życiem Polaków, jak i popkulturowymi wyobrażeniami erotyki i seksualności. Na rynku pojawiały się nie tylko poradniki seksuologiczne, ale także niestroniące od erotyki powieści, także dla młodzieży. W czasopismach, zwłaszcza skierowanych do dziewcząt, coraz częściej podejmowano problemy związane z życiem seksualnym. Nagość, oczywiście stosownie reglamentowana, była także coraz bardziej widoczna w telewizji.

Znaczenie miał także wpływ kultury wideo i kina zachodniego. Zdawali sobie $\mathrm{z}$ tego sprawę także przedstawiciele władzy, wskazując, że jeżeli chodzi o nagość, reagujemy na to, co dzieje się w kulturze światowej, staramy się dotrzymać 
kroku Zachodowi[2]. Oczywiście kino polskie nie miało szansy rywalizować $\mathrm{z}$ wideo pod tym względem. Niemniej jednak, aby przyciągnąć widzów do kin, jak również przed ekrany telewizorów, należało zapewnić, przynajmniej w pewnej mierze, ofertę konkurencyjną. Nagość miała więc nie tylko przyciągnąć ludzi do kin, ale i odciągnąć ich od filmów wideo, stanowić ofertę odwołującą się do tych samych potrzeb, ale - według ówczesnej wykładni - znacznie bardziej wartościową[3], przy okazji zaś zapewniając odbiorcy poczucie przynależności do nowoczesnego (zachodniego) świata.

Władza nie miała nic przeciw nagości. Jej przedstawiciele podkreślali wręcz, że jeśli tylko nagość jest uzasadniona, cenzura ją dopuszcza: „podstawową przesłanką jest szerokie myślenie o całokształcie ocenianego dzieła" [4]. Takie nastawienie nie było przypadkowe. Zapewne zbyt mocno formułował swoje tezy, zaraz po przełomie transformacyjnym, Jerzy Krysiak, który, wskazując na brutalizację i amoralne traktowanie seksu w latach 8o., łączył to zjawisko z „seksualną demaskacją władzy" [5] i sugerowal, że gwałt w seksie odzwierciedlał gwałt władzy na społeczeństwie. Niemniej jednak związki polityki i seksu były bez wątpienia istotne. W kulturze opresyjnej nagość umożliwiała podjęcie takich kwestii, które w inny sposób nie mogłyby zaistnieć, ale też służyła systemowi politycznemu, który dzięki niej zaspokajał niektóre potrzeby społeczeństwa, osłabiając tym samym możliwość ewentualnego wystąpienia przeciw władzy. Dostrzegając przykłady obu rozwiązań, Izabela Kalinowska większe znaczenie przypisywała jednak temu drugiemu[6].

Z pewnością w kinematografii można dostrzec chęć neutralizacji politycznych nastrojów. Kino miało być jednym z elementów odwracających uwagę Polaków od sytuacji politycznej w kraju.

Naga władza, pozbawiona listka figowego marksizmu, nie sprzeciwiała się już nagości. Wręcz przeciwnie - na jej antyspołecznym, eskapistycznym potencjale bardzo jej zależało. Dlatego filmowa rozrywka wydawała się dobrym narzędziem do rozrywania zawiązanych przed 13 grudnia więzi społecznych[7].
Nie bez powodu, zauważa Krzysztof Kornacki, nasilenie filmów o tematyce erotycznej przypada na lata 1984-1985, a więc krótko po zawieszeniu stanu wojennego. Trzeba było zapewnić widzom rozrywkę i odciągnąć uwagę od szarej polityczno-społecznej rzeczywistości. Nie oznacza to jednak, że rachunek ekonomiczny był nieistotny, przeciwnie - miał pierwszorzędne znaczenie. Krytyka filmowa doskonale zdawała sobie z tego sprawę.

[...] odkąd zapanowała kinematograficzna reforma, wisi nad każdym z filmów dość prymitywnie realizowany „przymus kasy”. Ujawnia się on zawsze w ten sam sposób: jako sowite okraszanie taśmy, niezależnie od treści filmu, seksem. Sceny półpornograficzne, a nieraz całkiem pornograficzne, pojawiają się niezależnie od potrzeb dramaturgicznych i w związku z akcją [8].

Malatyńska korzystała z prawa publicystycznej przesady, przy okazji nazywając „pornografią" wszystko, co erotyczne, trudno jednak odmówić jej racji. Ale strategia ta przynosiła rezultaty. Edward Zajiček podaje, że w roku 1984 tylko 10 filmów zwróciło koszty rozpowszechniania (w tym sporządzenia kopii), a jedynie

Urzędu Kontroli Publikacji i Widowisk w Warszawie, „Film” 1983, nr 45, s. 19.

[3] Zob. P. Wasiak, „Zwoje muskułów monstrualnych rozmiarów i dużo nagiego ciała”. Kultura popularna, nowe technologie medialne i legitymizacja socjalistycznego projektu kulturowego, w: Kultura popularna w PRL, red. B. Giza, P. Zwierzchowski, „Kultura Popularna” 2014, nr 2.

[4] Starać się działać mądrze..., s. 18.

[5] J. Krysiak, Romans z władza, „Kino” 1990, nr 8, s. 18.

[6] I. Kalinowska, Seks, polityka i koniec PRL-u: o cielesności w polskim kinie lat osiemdziesiatych, w: Ciało i seksualność w kinie polskim, red.

S. Jagielski, A. Morstin-Popławska, Kraków 2009, s. 69,74 .

[7] K. Kornacki, Naga władza. Polskie kino erotyczne (schyłkowego PRL-u), w: Niebo i piekło melodramatu, red. S. Bobowski, „Studia Filmoznawcze" Wrocław 2008, t. 29, s. 203.

[8] M. Malatyńska, Klisze z klisz, „Życie Literackie” 1985, nr 39, s. 12. Zob. też: M. Malatyńska, Filmowe gry z literatura, „Życie Literackie” 1986, nr 39, s. 12. 
trzy przyniosły wpływy, które pozwoliły na pokrycie kosztów produkcji. Były to Seksmisja Juliusza Machulskiego, Thais Ryszarda Bera oraz Widziadło Marka Nowickiego. Kolejny rok był pod tym względem jeszcze gorszy. Z 40 filmów tylko jeden - Och, Karol! Romana Załuskiego zwrócił się całkowicie, a dwa były bliskie tego sukcesu: Alabama Ryszarda Rydzewskiego i $\mathrm{Va}$ bank II Machulskiego [9]. Nietrudno zauważyć, że, oprócz tego ostatniego, ważnym elementem wszystkich pozostałych była nagość. Nic więc dziwnego, że coraz częściej powstawały filmy, w których stanowiła ona nader istotny element, choć częściej ornamentacyjny niż wynikający z sensów i znaczeń filmu.

Kino usprawiedliwiało nagość na wiele sposobów. Jednym z najczęściej stosowanych i stanowiących najsilniejszy argument było sięgnięcie do literatury, co ważne - nie współczesnej, ale do klasyki[10], choć niekoniecznie najbardziej znanej. O ile jednak krytycy zwracali uwagę na fakt, że Widziadło było strywializowaną adaptacją Pałuby Karola Irzykowskiego, dla większości widzów nie miało to żadnego znaczenia. Fotosy, plakaty, a przede wszystkim szeptana reklama sprawiały, że do kin wybierali się także ci, którzy liczyli na sporo nagości. To samo dotyczyło Thais czy Łuku Erosa Jerzego Domaradzkiego.

Ale ta strategia przekładała się również na wizualizowanie nagości. Skoro tak bardzo liczyły się artystyczne i estetyczne konotacje, tego samego wymagano od wizerunków nagiego ciała. Ponadto, nagość musiała być „moralna”, z jednej strony, w odróżnieniu od zachodniej, z drugiej, by nie naruszać cały czas jeszcze silnych, mimo zauważalnych zmian, obyczajowych konwenansów. Ich przeobrażenia wraz z czasem są zresztą wyraźnie widoczne. Bardziej odważne, zarówno w odniesieniu do nagości, jak i w ogóle scen seksu, kino polskie staje się $\mathrm{w}$ drugiej połowie

[9] E. Zajiček, Poza ekranem. Polska kinematografia w latach 1896-2005, Warszawa 2009, s. 286.

[10] T. Lubelski, Historia kina polskiego. Twórcy, filmy, konteksty, Katowice 2009, s. 494.

[11] K. Kornacki, op.cit., s. 217.

[12] Ibidem, s. 216-217. dekady. W pierwszej dominują akty, natomiast relacje seksualne bohaterów są zaledwie sugerowane, ukazywane urywkowo bądź w sposób na tyle „artystyczny”, że prawie nieczytelny[11]. Dominowały biusty i pośladki, bardzo rzadko pojawiały się włosy łonowe. Krzysztof Kornacki słusznie zwraca uwage, że w sposobie fotografowania „niemal zawsze obecny jest pierwiastek estetycznej kompozycji (niektóre fotosy z Widziadła, Thais czy Kamiennych tablic mogłyby zdobić kalendarze). To zapewniało «artystyczność» filmowi, a twórcom spokój, że nie będą oskarżenie o demoralizację"[12].

Wykorzystywano także wzory i konwencje kulturowe z przeszłości jako swoiste intertekstualne odniesienie (Młoda Polska, dwudziestolecie międzywojenne), stosowano chwyty, które umożliwiały wprowadzenie nagości do świata przedstawionego. Jednym $\mathrm{z}$ najbardziej popularnych było umieszczenie w filmie sceny ze striptizem, będącego tą specyficzną formą udziału w kulturze popularnej, która kojarzyła się przede wszystkim z kulturą Zachodu. Wykorzystując nagość do krytyki permisywizmu, jak w Menedżerze Ryszarda Rydzewskiego, czy przemysłu rozrywkowego, jak choćby w Bohaterze roku Feliksa Falka, czyniono to przecież, ukazując ją samą i zwiększając w ten sposób atrakcyjność mało ciekawych w gruncie rzeczy filmów. Co znamienne, podobne zabiegi - nagość ilustrowała krytykujące ją artykuły - stosowano w prasie filmowej.

Jako uzasadnienie dla ekranowej nagości przyjmowano także specyfikę niektórych gatunków, choć w gruncie rzeczy jako element promocji filmu nie była zależna od konotacji gatunkowej. Pojawiała się w filmach obyczajowych (Karate po polsku Wojciecha Wójcika, 1982, Kamienne tablice Ewy i Czesława Petelskich, 1983, Yesterday Radosława Piwowarskiego, Alabama Ryszarda Rydzewskiego, oba 1984, Sceny dziecięce z życia prowincji Tomasza Zygadły, Menedżer Rydzewskiego, oba 1985, Łuk Erosa Jerzego Domaradzkiego, Pociag do Hollywood Piwowarskiego, oba 1987), komediach (Seksmisja i Kingsajz Juliusza Machulskiego, 1983, 1987, Och, Karol Romana Załuskiego, 
1985, Sztuka kochania Jacka Bromskiego, 1989), horrorach (Widziadło Marka Nowickiego, 1983, Wilczyca i Powrót wilczycy Marka Piestraka, 1982, 1990, Lubie nietoperze Grzegorza Warchoła, 1985), filmach sensacyjnych i kryminalnych (Wielki Szu Sylwestra Chęcińskiego, 1982, Magiczne ognie Janusza Kidawy, 1983, Kim jest ten człowiek Petelskich, 1984, Zabij mnie glino Bromskiego, 1987, 11 odcinków serialu o7 zgłoś się), Trójkąt bermudzki Wojciecha Wójcika, 1987), fantastycznych ( $G a, g a$, Chwała bohaterom Piotra Szulkina, 1985), kostiumowych (Epitafium dla Barbary Radziwiłtówny Janusza Majewskiego, 1982, Thais Ryszarda Bera, 1983, Spowiedź dziecięcia wieku Marka Nowickiego, Ognisty anioł Macieja Wojtyszki, oba 1985), kinie politycznym z końca dekady (Chce mi się wyć Jacka Skalskiego, Ostatni dzwonek Magdaleny Łazarkiewicz, Ostatni prom Waldemara Krzystka, wszystkie 1989), jak również w ekranizacjach oper (Szkoła kochanków, czyli cosi fan tutte Krzysztofa Tchórzewskiego, 1987). Nawet legendarne Przestuchanie (1982/1989) Ryszarda Bugajskiego, rozpowszechniane $\mathrm{z}$ kaset wideo podczas nielegalnych seansów, ukazujące między innymi upokarzanie kobiet przez system polityczny, można, podobnie jak Nadzór (1983) Wiesława Saniewskiego, potraktować jako specyficzne polskie wersje prison movie, wpisane w konteksty historyczne i współczesne, ale wykorzystujące także związane $\mathrm{z}$ nagością klisze.

Nagość kojarzyła się z niektórymi aktorkami, których obecność w filmie zdawała się ją gwarantować. Szczególny status zyskały trzy: Grażyna Szapołowska, Katarzyna Figura i Maria Probosz. Ta ostatnia zagrała wówczas w ponad 30 polskich filmach fabularnych i telewizyjnych, w tym w serialach - w 19 wystąpiła nago, podobnie jak w trzech filmach zagranicznych[13]. Były to często role drugoplanowe lub wręcz epizodyczne, ale tak bardzo kojarzyła się z nagością, że stała się ona wręcz jej specyficzną specjalnością.

Nagość miała przyciągnąć widzów do kina, zarówno dzięki samym filmom, jak i plakatom czy też fotosom prezentowanym w prasie oraz gablotach reklamowych przed kinami, cza- sopismom ilustrowanym oraz prasie filmowej[14]. Remigiusz Włast-Matuszak, pisząc w 1984 roku o reklamie filmowej, traktował ją jako coś nieistniejącego[15]. Wskazywał, że kryzys ekonomiczny lat 1980-1981 skłonił decydentów do większego zaangażowania w reklamę, by przyciągnąć do kin jeszcze większą liczbę widzów. Autor w tekście nie wskazywał na konkretne pomysły, zajmował się raczej instytucjonalną strukturą reklamy filmowej, ale interesujący $\mathrm{w}$ tym kontekście jest materiał wizualny. Zamieszczone przykłady reklamy pochodzą z kinematografii zachodniej, między innymi z Emmanuelle 4 Francisa Leroi. Nacisk jest $\mathrm{w}$ nich położony na erotykę i przemoc. Jako kontrapunkt został zamieszczony plakat z Pastorale heroica Henryka Bielskiego jako przykład postulowanej przez krytyków i twórców „reklamy intelektualnej, mądrej, subtelnej i prawdomównej", niekoniecznie jednak trafiającej do widzów.

Nie odmawiając autorowi racji, trzeba wszakże podkreślić, że w latach 8o. właśnie erotyka bardzo często była elementem promocji filmu. Roznegliżowane aktorki można było zobaczyć nie tylko w kinach, ale także w ilustrowanej prasie filmowej. Ich zdjęcia pojawiały się już nie tylko jako ilustracje recenzji czy artykułów, ale także na okładkach (oczywiście dotyczyło to aktorek zarówno polskich, jak i zagranicznych). Można nawet zauważyć różnice między poszczególnymi czasopismami: choć i w „Filmie” nie brakowało nagości, recenzje w „Ekranie” częściej były ilustrowane fotosami przedstawiającymi nagie aktorki[16].

[13] Były to niemieckie Junge Leute in der Stadt (1985) Karla Heinza Lotza, czechosłowacka Cena odvahy (1986) Ludovita Filana oraz radziecki Czas potnotunija (1988) Arunasa Zebriunasa.

[14] Por. K. Kornacki, op.cit., s. 201.

[15] R. Włast-Matuszak, Reklama filmowa a sposób myślenia, „Ekran” 1984, nr 14, s. 2.

[16] M. Winiarczyk, Horror rodem z Irzykowskiego, „Ekran” 1984, nr 16, s. 16; idem, Atrakcyjna demaskacja [to tylko rock], „Ekran” 1984, nr 26, s. 16; idem, Papierowy antyk. „Ekran” 1984, nr 40, s. 17. Cz. Dondziłło, Eros psychoanaliza podszyty, „Film” 1984, nr 20, s. 9; B. Umińska, „Pałuba” 
Nagość nie tylko zachęcała do pójścia do kina na filmy wchodzące właśnie na ekrany, ale także wzmagała oczekiwanie na te, które dopiero były w realizacji. Przykładem mogą być materiały o powstawaniu Idola Feliksa Falka[17] czy kolejnych odcinków popularnego serialu kryminalnego of zgłoś się[18].

Oczywiście, czasopisma filmowe promowały w ten sposób nie tylko filmy, ale także same siebie. Polski rynek wydawniczy nie oferował wówczas żadnych czasopism stricte erotycznych, co nie oznacza, że na łamach prasy nie można było znaleźć roznegliżowanych kobiet. Niektóre tytuły dzięki zamieszczaniu takich zdjęć budowały wręcz swoją pozycję, czego przykładem może być tygodnik „Razem”. Adresowany do młodzieży i poświęcony jej problemom, pod koniec dekady w dużej mierze kupowany był dla plakatów zespołów muzycznych i zamieszczonego na ostatniej stronie zdjęcia nagiej kobiety. „Nagie” zdjęcia w „Filmie” czy „Ekranie” budziły zainteresowanie nie tylko wśród miłośników kina. Dlatego też wykorzystywano różne okazje, by je zamieszczać.

To oczywiście naturalne, że poświęcony erotyce i nagości w polskim kinie cykl wywiadów Ilony Łepkowskiej z przedstawicielami różnych specjalności był bogato ilustrowany fotosami, głównie, choć nie tylko, z polskich filmów[19]. Jak już jednak wspomniałem, zdjęcia rozebranych kobiet nierzadko towarzyszyły też artykułom krytycznym wobec kultury zachodniej, piętnującym na przykład seksualną

jako „Widziadło”, „Film” 1984, nr 22, s. 9; M. Pawlicki, Niecały ten rock, „Film” 1984, nr 27, s. 9.

[17] Idol, „Ekran” 1984, nr 33, s. 8.

[18] o7 zgłoś się, „Ekran” 1984, nr 27, nr 9.

[19] Seks a kultura. Rozmowa z socjologiem doc. dr Marią Trawińską, „Film” 1983, nr 32, s. 3-5; Odkrycie erotyzmu. Rozmowa $\mathrm{z}$ dr. Lechosławem Gapikiem z Uniwersytetu im. Adama Mickiewicza, psychologiem, seksuologiem, psychoterapeutą, „Film” 1983, nr 36, s. 6-8; Czy to czymś grozi? Rozmowa z lekarzem, seksuologiem dr. hab. Andrzejem Jaczewskim, prodziekanem Wydziału Pedagogiki Uniwersytetu Warszawskiego, „Film” 1983, nr 42, s. 10-11, 17; Starać się działać madrze..., s. 18-19. swobodę. Stały się także obowiązkową pozycją $\mathrm{w}$ fotoreportażach $\mathrm{z}$ festiwalu $\mathrm{w}$ Cannes, prezentując kobiety próbujące zwrócić na siebie uwagę poprzez nagość. Jakkolwiek pisano przy okazji o targowiskach próżności, piętnując w ten sposób obyczaje obowiązujące w krajach kapitalistycznych, to przecież uatrakcyjniano w ten sposób wizualną warstwę czasopisma. Tak samo działo się w wypadku tekstów świadczących o niskiej wartości artystycznej filmów funkcjonujących na kasetach wideo. Odpowiednio dobrane zdjęcia tyleż ilustrowały tezy autorów, co cieszyły oko czytelnika, rzecz jasna przede wszystkim płci męskiej.

Fotosy publikowano w czasopismach, zamieszczano je również $\mathrm{w}$ gablotach reklamowych, najczęściej przed kinami. W połowie lat 8o. trzynastoletni chłopak, wracający ze szkoły, przechodził obok dużej witryny, w której reklamowano najnowszy repertuar filmowy. Dopiero zaczynał interesować się kinem, ale już pilnie śledził wszystkie nowości, które miały pojawić się na ekranach. Szczególnie często wywieszano plakaty i fotosy zapowiadające filmy polskie, przynajmniej taki obraz zachował się w mojej pamięci. Z pewnością przyglądałem się wszystkim fotosom, zapamiętałem niektóre. Wśród nich znalazły się na przykład Thais Ryszarda Bera, Magiczne ognie Janusza Kidawy i Ognisty anioł Macieja Wojtyszki. Nic o nich nie wiedziałem, ale nagość aktorek przyciągnęła moją uwagę. Pamiętam, jak z żalem myślałem o tym, że nie wpuszczą mnie do kina z powodu mojego wieku. Oglądając te filmy po latach, dziwiłem się, jak mało istotne, oprócz Thais, były w nich sceny nagości. Niemniej jednak to właśnie te zdjęcia przyciągnęły moją uwagę.

Nietrudno też zauważyć, że na przełomie lat 70. i 80. nastąpił gwałtowny wzrost liczby plakatów, w których nagość stanowiła dominantę kompozycyjną i tematyczną. Polskie plakaty filmowe lat 80 . z pewnością miały duże walory artystyczne (fotosy z filmów były jeszcze wykorzystywane stosunkowo rzadko), zresztą ich twórcami byli wybitni artyści, by wspomnieć Franciszka Starowieyskiego, Waldemara Świerzego, Jakuba Erola, Andrzeja Pągowskiego, Sta- 
sysa Eidrigevičiusa, Jerzego Dudę-Gracza, Jana Młodożeńca, Rafała Olbińskiego. Nie oznacza to jednak, że stroniły od nagości (niektórzy $\mathrm{z}$ wymienionych, jak Pągowski czy Starowieyski, szczególnie chętnie z niej korzystali).

Przykładami mogą być plakaty do takich filmów jak: Czas dojrzewania, Epitafium dla Barbary Radziwitłówny, Femina, Kobieta w kapeluszu (wersja ang.), Gdzieśkolwiek jest, jeśliś jest..., Kingsajz, Konopielka, Lubię nietoperze, Łuk Erosa (jeden z plakatów do tego filmu, autorstwa Andrzeja Pągowskiego, jest szczególnie dwuznaczny, ponieważ kobieca twarz staje się na nim częścią penisa), Marcowe migdały, Nadzór, Och Karol, Penelopy, Spowiedź dziecięcia wieku, Szkoda twoich łez, Szkoła kochanków czyli Cosi fan tutte, Tabu, Thais, Widziadło, Wilczyca, Wojna światów - następne stulecie, Yesterday (nieco odmienny jest plakat do Zygfryda, ponieważ eksponuje męską nagość). Była to nagość mniej lub bardziej wyeksponowana, pojawiająca się również przy promocji tych filmów, w których nie stanowiła motywu dominującego, nie odgrywała zbyt istotnej roli dramaturgicznej, a nawet - była elementem wręcz epizodycznym, nie pozostawiając jednak wątpliwości, że widz, który wybierze się do kina, może na nią liczyć.

Niekiedy nagością posługiwało się kilka plakatów do jednego filmu. $Z$ trzech plakatów promujących Thais dwa, autorstwa Jakuba Erola, wykorzystywały nagość, choć pierwszy z nich tylko ją sugerował. Drugi był bardziej dosłowny, ze zdjęciem aktorki. Spośród czterech plakatów reklamujących Widziadło w trzech została wykorzystana nagość, choć w różnej formie. W plakacie zaprojektowanym przez Jadwigę i Leszka Drzewińskich w pierwszej chwili dostrzegamy tylko twarz aktora, zdającą się wypełniać całą przestrzeń. Dopiero później zdajemy sobie sprawę, że jest w nią wpisany rysunek przedstawiający nagą kobietę. Kolejny, nieznanego autorstwa, wykorzystuje słynny obraz Władysława Podkowińskiego Szał. Trzeci, Marii Ihnatowicz, jest najbardziej dosłowny rysunek eksponuje biust kobiety i burzę rudych włosów.
Nagość wykorzystana jako element przyciągający uwagę przesłaniała właściwy pomysł. $\mathrm{Na}$ zrobionym przez Antoniego Chodorowskiego plakacie do Czasu dojrzewania Mieczysława Waśkowskiego narysowana naga dziewczyna trzyma w ręku makówkę, jednoznacznie wskazującą na narkomanię jako główny problem filmu. Plakat ten obrazuje jednocześnie problem z postrzeganiem Czasu dojrzewania, w którego odbiorze nagość, w gruncie rzeczy dość ograniczona, dominowała.

Plakaty te można było rzecz jasna odczytywać na kilku poziomach: $\mathrm{z}$ jednej strony doceniać artystyczny koncept, pomysł graficzny, subtelność skojarzeń, z drugiej - dostrzec w nim po prostu ofertę nagości. Znamienny jest tu plakat Andrzeja Pągowskiego do Epitafium dla Barbary Radziwiłłówny Janusza Majewskiego. Obnażony tors kobiety spowija kilka pogrzebowych bandaży. Nie widzimy górnej części jej twarzy, uwaga została skupiona na ciele, ukazanym niczym na zdjęciu w magazynie erotycznym. Ale całość jest stylizowana na portret trumienny z epoki. W kontekście filmu, opowiadającego o miłości króla Zygmunta Augusta i Barbary Radziwiłłówny, przerwanej przez jej śmierć, połączenie Erosa z Tanatosem jest trafne i uzasadnione, a przy tym bardzo ciekawe plastycznie. Niemniej jednak, uwagę przyciąga przede wszystkim wyeksponowany spory biust. Jakkolwiek więc praca Pągowskiego jest przemyślaną, bardzo ciekawą kompozycją, odwołującą się do fabuły i znaczeń proponowanych przez film, promowała go także przez nagość, w pewnym sensie wyabstrahowaną z plakatu jako całości.

Tak jak wspominałem, kino przez nagość próbowało odwrócić uwagę od szarej rzeczywistości lat 8o., chciało się wpisać w światowe tendencje, zapewnić poczucie przynależności do nowoczesnego (zachodniego) świata, sprawić odbiorcy, przede wszystkim męskiemu, przyjemność wizualną. Uzasadnienia wykorzystania nagości nie były przecież pozbawione podstaw, bywała wpisana w fabułę i znaczenia filmu, jak również konwencję gatunkową, niekiedy dopełniała także artystyczną wypowiedź. 


\section{VARIA}

Trudno więc uznać, że stanowiła jedynie część strategii promocyjnej. Gdy jednak weźmiemy pod uwagę wszystkie związane z nią działania i konteksty, ta jej funkcja jawi się jako najważniejsza.

\section{B I B L I O G R A F I A}

07 zgłoś się, „Ekran” 1984, nr 33

Czy to czymś grozi? Rozmowa z lekarzem, seksuologiem dr. hab. Andrzejem Jaczewskim, prodziekanem Wydziału Pedagogiki Uniwersytetu Warszawskiego, 1983, „Film” nr 42

Dondziłło Cz., Eros psychoanaliza podszyty, „Film” 1984, nr 20

Idol, „Ekran” 1984, nr 33.

Kalinowska I., Seks, polityka i koniec PRL-u: o cielesności $w$ polskim kinie lat osiemdziesiątych, w: Ciało i seksualność $w$ kinie polskim, red. S. Jagielski, A. Morstin-Popławska, Kraków 2009

Kornacki K., Naga władza. Polskie kino erotyczne (schyłkowego PRL-u), w: Niebo i piekło melodramatu, red. S. Bobowski, „Studia Filmoznawcze”, Wrocław 2008, t. 29

Kornatowska M., Eros i film, Łódź 1986

Krysiak J., Romans z władza, „Kino” 1990, nr 8

Lubelski T., Historia kina polskiego. Twórcy, filmy, konteksty, Katowice 2009

Malatyńska M, Filmowe gry z literatura, „Życie Literackie" 1986, nr 39
Malatyńska M., Klisze z klisz, „Życie Literackie” 1985, nr 39

Odkrycie erotyzmu. Rozmowa z dr. Lechosławem Gapikiem z Uniwersytetu im. Adama Mickiewicza, psychologiem, seksuologiem, psychoterapeutą, „Film” 1983, nr 36

Pawlicki M., Niecały ten rock, „Film” 1984, nr 27

Seks a kultura. Rozmowa z socjologiem doc. dr Marią Trawińską, „Film” 1983, nr 32

Starać się działać mądrze. Rozmowa z Przemysławem Marciszem, dyrektorem Okręgowego Urzędu Kontroli Publikacji i Widowisk w Warszawie „Film”, 1983, nr 45

Umińska B., „Pałuba” jako „Widziadło”, „Film” 1984, nr 22

Wasiak P., „Zwoje muskułów monstrualnych rozmiarów i dużo nagiego ciała”. Kultura popularna, nowe technologie medialne i legitymizacja socjalistycznego projektu kulturowego, w: Kultura popularna w PRL, red. B. Giza, P. Zwierzchowski, „Kultura Popularna” nr 2, Warszawa 2014

Winiarczyk M., Atrakcyjna demaskacja, „Ekran” 1984, nr 26

Winiarczyk M., Horror rodem z Irzykowskiego, „Ekran” 1984, nr 16

Winiarczyk M., Papierowy antyk. „Ekran” 1984, nr 40

Włast-Matuszak R., Reklama filmowa a sposób myślenia, „Ekran” 1984, nr 14

Zajiček E., Poza ekranem. Polska kinematografia $w$ latach 1896-2005, wyd. II uzupełnione i rozszerzone, Warszawa 2009 